\title{
A Case Study of Symptomatic Pubertal Bilateral Gynaecomastia and Role of GnRH in Management
}

\author{
Aye $\mathbf{M}^{* 1}$, Cabot $\mathrm{JSF}^{2}$, Thanabalan $\mathrm{MC}^{3}$ and Baba $\mathrm{S}^{4}$ \\ ${ }^{1}$ Department of Medicine, Melaka Manipal Medical College, Malaysia \\ ${ }^{2}$ Department of Medicine, Uni KL Royal College of Medicine, Perak, Malaysia \\ ${ }^{3}$ Medical Officer, Hospital Sungai Siput, Malaysia \\ ${ }^{4}$ Department of Radiology, Ipoh General Hospital, Malaysia
}

"Corresponding author: Aye M, Department of Medicine, Melaka Manipal Medical College, Malaysia, Tel: 243 2635 2637; E-mail: mraaye@hotmail.com

Received date: April 08, 2014, Accepted date: May 20, 2014, Published date: May 28, 2014

Copyright: (c) 2014 Aye M, et al. This is an open-access article distributed under the terms of the Creative Commons Attribution License, which permits unrestricted use, distribution, and reproduction in any medium, provided the original author and source are credited.

\begin{abstract}
Pubertal gynaecomastia is a common condition, usually disappearing within three years of onset. Enlargement of the breast rather than pain is the most common symptom. We report a case of painful severe persisting pubertal gynecomastia for more than four years in an adolescent boy requiring surgery; consider it's the mechanism in puberty and the role of gonadotropin releasing hormone $(\mathrm{GnRH})$ stimulation test in its management.
\end{abstract}

Keywords: Painful; Severe; Bilateral; Pubertal Gynecomastia (PG); GnRH

\section{Introduction}

Trimodal distribution for asymptomatic gynecomastia is noted (neonatal, pubertal, and in elderly males. Prevalence of symptomatic gynecomastia is markedly low [1]. Puberty, the second age range in which gynecomastia develops is usually physiological. Up to $60 \%$ of boys have detectable gynecomastia by age 14 [2]. Although it is mostly bilateral, it can occur unilaterally, and usually resolves within three years of onset [3]. Some studies show a decreased androgen to estrogen ratio exists in boys with pubertal gynecomastia (PG) with presumably aromatase playing a pivotal role [4,5]. The adult testes normally directly secrete almost $15 \%$ of circulating estradiol and less than $5 \%$ of estrone. The rest of the estradiol and estrone in the circulation are produced in extra-glandular sites through aromatization of testosterone (to estradiol) and androstenedione (to estrone). Estrone and estradiol are interconverted, as are androstenedione and testosterone through the action of 17-oxosteroid reductase, which is widely distributed in various tissues. Aromatase activity has been demonstrated in the placenta, ovary, testes, brain, skin fibroblast, adipocytes, normal breast stromal cells and fetal tissues [5]. Thus, the mechanism by which pubertal gynecomastia (PG) occurs may be due to either decreased production of androgens, increased aromatization of circulating androgens, increased activity of aromatase or over-expression of aromatase activity resulting in an increasedestrogen to androgen ratio.

In males, puberty is considered delayed if testicular enlargement does not occur by 14 years of age, there is lack of pubic hair by age 15 years, or more than five years are required to complete genital enlargement and evaluation of delayed puberty is recommended in females at 13 year and males at 14 year, or older who do not demonstrate signs of sexual maturation [6,7]. Mean chronological age of puberty in boys is 11.5 years and in girls is 11 years [8]. Onset of puberty usually corresponds to a bone age of 11-12 [9]. The most common cause of delayed puberty is constitutional delayed puberty
(CDP). GnRH testing can be helpful in distinguishing CDP from idiopathic gonadotropin deficiency. However, there is considerable overlap among prepubertal, early pubertal, and hypo gonadotrophic responses. Bone age can also be useful in distinguishing idiopathic gonadotropin deficiency from CDP. In patients with CDP, bone age will be delayed but puberty will begin at a pubertal bone age. However, there are currently no available lab tests to definitely distinguish between these entities. Eventual onset and progression of puberty is the sole method to positively distinguish CDP from hypo gonadotrophic hypogonadism [10].

\section{Case in Detail}

In 2010, a 13.5 year-old Indian boy was referred for very painful, severe gynecomastia. The patient claimed to have had gynecomastia for more than four years. It was of sudden onset and severe painful and disturbed the sleep and school attendance. Both breasts were affected equally and there was no discharge. He could not hide this problem and was teased by his peers resulting in psychological trauma. He had neither other endocrine and systemic symptoms nor eating disorders. There was no history of severe stress. He had been on a normal diet. He did engage in strenuous exercise. He had been diagnosed with epilepsy at age nine. He had taken three antiepileptic drugs for two years and he then spontaneously discontinued treatment and suffered no further seizures. Other past medical, surgical, family and drug histories were not relevant. He was third of five siblings, with two brothers and two sisters healthy. While there was no family history of gynecomastia, his parents were unsure about their own pubertal developments. His school performance was average. He did not smoke or use illicit drugs.

Physical examination revealed tender bilateral gynecomastia: about $5 \times 5 \mathrm{~cm}$ in diameter (Plate 1). 


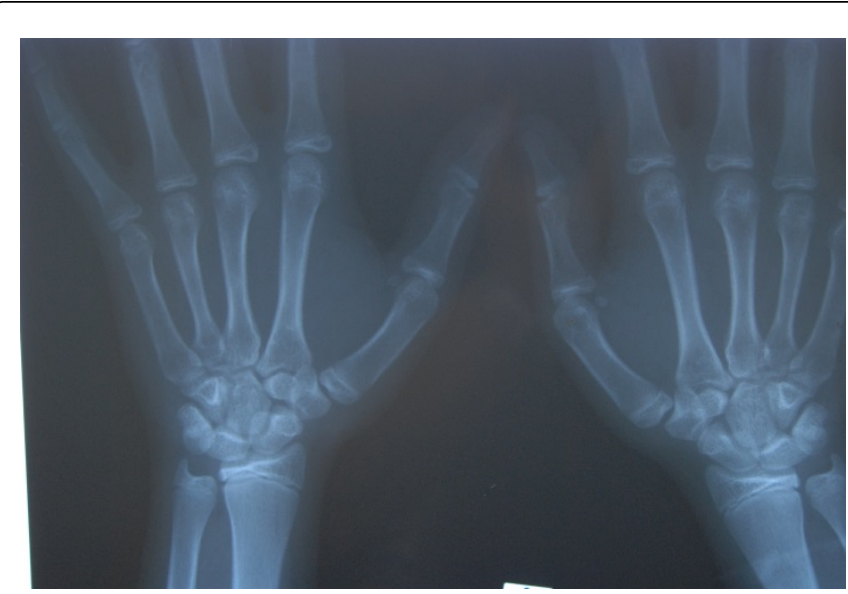

Plate 1: Physical examination revealed tender bilateral gynecomastia.

There was no spontaneous or pressure discharge. No lumps were palpated. His height was $156 \mathrm{~cm}$, at 25th percentile range for his age. Mother's and father's heights were 162 and $153 \mathrm{~cm}$ respectively and his expected mid-parental height was $155-172 \mathrm{~cm}$. Weight was $61.5 \mathrm{~kg}$ with BMI 25.3. Weight was 90th percentile range. Puberty assessment was Tanner stage 1 . Blood pressure was $120 / 80 \mathrm{mmHg}$. Skin texture was smooth. Other physical examination was normal. There were no features to suggest Turners, Klinefelter, Prader Willi or Kallmann syndromes. Sense of smell, hearing, visual fields and optic discs were normal.

As the pain was severe, he was seen by both general surgeon and endocrine consultants. Breast reduction surgery was advised by the endocrine consultant and was performed six months after the medical consultation at age 14. The histopathology of both breasts showed fibro-fatty breast tissues containing some scattered lobular ductules, all lined by dual cells layer. The surrounding stroma was hyalinised. No evidence of malignancy. The pathologist reported as chronic gynecomastia. It was consistent with notion by Johnson RE et al. [1]. He had no more pain and psychological distress after the surgery.

Persistent very painful gynecomastia for four years leads us to evaluate the cause of gynecomastia. Tanner stages 1 at chronological age 14 and bone age 13 lead us to evaluate for delayed puberty although he had voice changes and attained mid-parental height at the age 13.5 and when the parents were unaware of their pubertal developments. The results for basal sex hormones and other hormones are shown in Table 1.

\begin{tabular}{|l|l|l|l|l|l|}
\hline Hormones & Normal range & Basal (6.2010) & $\mathbf{1 2 . 2 0 1 0}$ & $\mathbf{6 . 2 0 1 1}$ & $\mathbf{1 . 2 0 1 2}$ \\
\hline $\mathrm{LH}$ & $1.7-8.6 \mathrm{IU} / \mathrm{L}$ & 1.6 & 1 & 1.6 & 2.2 \\
\hline $\mathrm{FSH}$ & $1.5-12.4 \mathrm{IU} / \mathrm{L}$ & 1.6 & 1.7 & 1.8 & 2.3 \\
\hline Testosterone & $3.8-17 \mathrm{nmol} / \mathrm{L}$ & 1.26 & 1.56 & 3.8 & 13.38 \\
\hline Oestradiol & $28-156 \mathrm{pmol} / \mathrm{L}$ & 84.7 & 19.4 & 78 & 137.5 \\
\hline Androstenedione & $0.1-3 \mathrm{nmol} / \mathrm{L}$ & 1.1 & & & \\
\hline
\end{tabular}

Table 1: Basal and six monthly sex hormone assay reports
A normal androsteindione level ruled out 17-ketoreductase deficiency as a cause. Normal 17-ketosteriod and 5dehydrotestosterone ruled out congenital adrenal hyperplasia and androgen producing tumors of the adrenals. Karyotyping revealed chromosomes XY. Normal renal profile, liver function tests, chest Xray and echocardiogram ruled out systemic diseases as a cause of delayed puberty. Ultrasonography of testes and kidneys for evidence of local testes disease and congenital anomalies of kidneys as features of Kallman's syndrome and adrenal tumors respectively were normal. Imaging tests (CT and MRI of the brain) to rule out pituitary tumors and olfactory tract lesion, parts of Kallman's syndrome, were normal.

Six months later, the patient was reassessed for physical and hormonal development of puberty. Bone age 13, chronological age 14, sex hormone results indicating hypo gonadotrophic hypogonadism lead to a GnRH stimulation test and test result is shown in Table 2.

\begin{tabular}{|l|l|l|}
\hline Tests & Results & Normal range \\
\hline 17-hydroxyprogesterone & $0.7 \mathrm{nmol} / \mathrm{L}$ & $<6.0 \mathrm{nmol} / \mathrm{L}$ (for 12-20 yr) \\
\hline TSH & $4.85 \mathrm{mlU} / \mathrm{L}$ & $2.7-4.2$ \\
\hline T4 & $18.4 \mathrm{pmol} / \mathrm{L}$ & $12-22$ \\
\hline T3 & $6.7 \mathrm{pmol} / \mathrm{L}$ & $3.0-7.8$ \\
\hline Serum cortisol & $369 \mathrm{nmol} / \mathrm{L}$ & $171-536$ \\
\hline Serum prolactin & $3.06 \mathrm{ng} / \mathrm{ml}$ & $4.04-15.2$ \\
\hline
\end{tabular}

Table 2: Other endocrine function tests

By one year follow- up, testicular size increased to $6 \mathrm{ml}(>2.5 \mathrm{~cm}$ in length) and the blood testosterone level increased two fold. However, LH and FSH were still low and pubic hair was not noted. Serial six monthly sex hormones level are shown in Table 3.

\begin{tabular}{|l|l|}
\hline CT Scan of brain & Normal \\
\hline $\begin{array}{l}\text { MRI of pituitary and hypothalamus area and } \\
\text { olfactory bulbs }\end{array}$ & Normal \\
\hline Chest X-ray & Normal \\
\hline $\begin{array}{l}\text { 1st X- ray of left wrist for bone age (chronological } \\
\text { age 14) }\end{array}$ & Bone age 13 \pm months \\
\hline $\begin{array}{l}\text { 2nd Xray of left wrist on 13th Jan 2012 } \\
\text { (chonological age 16) }\end{array}$ & Bone age 15 \pm 7 months \\
\hline Ultrasonography of kidneys and testes & Normal \\
\hline Echocardiogram & Normal \\
\hline EEG & Normal \\
\hline
\end{tabular}

Table 3: Imaging and other procedures

Repeat physical examination, left wrist X-ray and sex hormone assay measurement were performed in Jan 2012 at chronological age 16. His height was $157 \mathrm{~cm}$. He had entered Tuners' stages two. Sex hormones ( $\mathrm{LH}, \mathrm{FSH}$, estradiol and testosterone level) were normal (Table 3). Bone age was reported at $15 \pm 3.7$ months (Plate 2). 


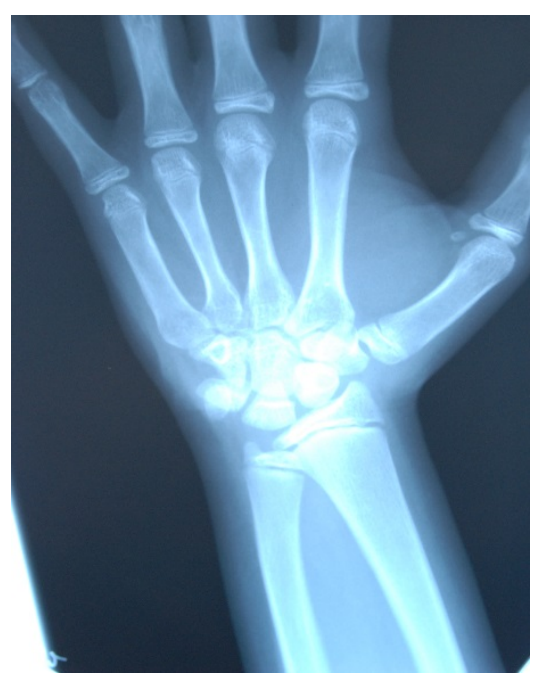

Plate 2: Bone age was reported

\section{Discussion}

Pubertal hormonal changes and overweight in this patient might have result in persistent gynecomastia [11]. However, increased aromatase activity in pubic skin fibroblasts in six patients with persistent PG and two with idiopathic gynecomastia was seen, [12] raising the possibility that local dysregulation of breast tissue aromatase may lead to a local estrogen to androgen imbalance. However, it has been reported in two different studies that the sex hormone profile in boys with PG is not different from that of boys without gynecomastia [13,14]. Woelfle JF [11] reported that persistence of PG beyond mid-puberty occurs mostly in overweight children, who also have elevated serum IGF-1 levels [11]. Thus, the concomitant occurrence of Peaked Height Velocity (PHV) and PG suggests that the rise in serum estrogen and IGF-1 levels both influence PHV and the development of PG. A study by Juul A et al. [15] that free insulin-like growth factor-I (IGF-1) serum levels had diagnostic value in patients suspected of growth hormone deficiency and Kleinberg DL et al. [16] reported in rats that IGF-1 exerts its maximal effect on the terminal end buds of the mammary gland in the presence of estradiol. Yehuda Limony et al. [17] reported that concomitant occurrence of gynecomastia and PHV suggests that both events have a common basis.

For various reasons, IGF-1 was not measured at the time of onset, presentation and investigation of gynecomastia.

Our patient showed some signs of puberty such as voice changes. Puberty is expected in boys by chronological age 11.5 years and bone age 11-12 years. He had a growth spurt attaining mid-pubertal height (25th centile range of height for his age). His parents while unaware of their pubertal development never heard of problems to suggest delayed puberty among their ancestors. One year discordance between chronological age and bone age is normal [18]. His height increased one $\mathrm{cm}$ only at age of 15 . Therefore, CPD is unlikely in this case. Normal androsteindione ruled out late onset deficiency of testicular 17-ketosteroid reductase as causes of male hypogonadism with gynecomastia [5]. Normal pituitary hormones except gonadotropins (Table 1), normal CT and MRI of brain (Table 3), normal blood tests and karyotyping (Table 4) pointed to isolated hypo gonadotrophic hypogonadism (IHH) although normal adult response to $\mathrm{GnRH}$ in this case was not consistent with $\mathrm{IHH}$ although occasionally in patients with isolated gonadotropin deficiency LH response to LH-RH has been reported [19]. Watchful waiting is generally recommended for the management of patients with delayed puberty [20].

\begin{tabular}{|l|l|l|}
\hline Hormones & Basal & after $\beta$ hCGinj: $\mathbf{x} 3$ days \\
\hline $\mathrm{LH}$ & $0.6 \mathrm{IU} / \mathrm{L}$ & $0.1 \mathrm{IU} / \mathrm{L}$ \\
\hline $\mathrm{FSH}$ & $1.8 \mathrm{IU} / \mathrm{L}$ & $0.44 \mathrm{IU} / \mathrm{L}$ \\
\hline Testosterone & $1.56 \mathrm{nmol} / \mathrm{L}$ & $23.88 \mathrm{nmol} / \mathrm{L}$ \\
\hline Estradiol & $21.4 \mathrm{pmol} / \mathrm{L}$ & $174 \mathrm{pmol} / \mathrm{L}(\mathrm{H})$ \\
\hline Androsteinedione & $<0.3 \mathrm{ng} / \mathrm{L}$ & $1.1 \mathrm{ng} / \mathrm{L}$ \\
\hline
\end{tabular}

Table 4: Sex hormones response to $\beta$ hCG stimulation test

However, normal adult response to GnRH in this case was not consistent with $\mathrm{IHH}$ although occasionally in patients with isolated gonadotropin deficiency $\mathrm{LH}$ response to $\mathrm{LH}-\mathrm{RH}$ has been reported [19]. Watchful waiting is generally recommended for the management of patients with delayed puberty [20]. However, late onset of sex hormone replacement in patients with hypogonadism will worsen outcome. In patients with delayed puberty aged 14 years and older, bone age usually exceeds 11 years in girls or 12 years in boys, thus in the range, where normal adult response of $\mathrm{LH}$ to $\mathrm{GnRH}$ may be expected. In contrast to patients aged less than 14 years, therefore, measuring GnRH stimulated LH levels in these patients allows for rapid and effective differential diagnosis of delayed puberty. A positive $\mathrm{LH}$ response to $\mathrm{LH}-\mathrm{RH}$ has important diagnostic and prognostic significance in the approach to the patient with delayed puberty $[18,21]$ and has some prognostic value in assessment of males presenting with delayed puberty. This patient attained puberty by chronological and bone age 15 and was planned for follow-up for continuing development of full puberty until age 17 .

In conclusion, low testosterone, decreased ratio of testosterone to estradiol, puberty and overweight caused persistent, severe symptomatic gynecomastia which required surgery. No sexual development by chronological age 14 and biological age 13, normal response to GnRH stimulation test and eventual sexual development by chronological and bone age 15 indicated growth and development appropriate for an individual's biologic age (skeletal age) rather than chronological age. Normal GnRH stimulation test is useful to positively prognoses boys who exceed bone age 12 and can follow a watch and wait policy. The case illustrates the difficulty of assessing the precise stage of puberty from individual clinical features and investigations (Table 5).

\begin{tabular}{|l|l|l|l|l|l|l|}
\hline & Basal level & $\begin{array}{l}\text { After } \\
\mathbf{2 0} \mathbf{~ m i n}\end{array}$ & $\mathbf{4 0} \mathbf{~} \mathbf{~ i n}$ & $\mathbf{6 0} \mathbf{~} \mathbf{~ i n}$ & $\mathbf{8 0} \mathbf{~} \mathbf{~ i n}$ & $\mathbf{1 0 0} \mathbf{~}$ in \\
\hline LH & $1.3 \mathrm{IU} / \mathrm{L}$ & 15.1 & 13.4 & 13.9 & 15.4 & 15 \\
\hline $\mathrm{FSH}$ & $1.6 \mathrm{IU} / \mathrm{L}$ & 3 & 3.1 & 3.3 & 3.8 & 3.6 \\
\hline Testosterone & $4.98 \mathrm{nmol} / \mathrm{L}$ & 3.84 & 4.41 & 4.29 & 4.71 & 4.96 \\
\hline Oestradiol & $78.2 \mathrm{pmol} / \mathrm{L}$ & 81.1 & 94.3 & 80.1 & 74.8 & 80.5 \\
\hline
\end{tabular}

Table 5: Sex hormones response to GnRH stimulation test 
Citation: Aye M, Cabot JSF, Thanabalan MC, Baba S (2014) A Case Study of Symptomatic Pubertal Bilateral Gynaecomastia and Role of GnRH in Management. J Metabolic Synd 3: 1000144. doi:10.4172/2167-0943.1000144

Page 4 of 4

\section{References}

1. Johnson RE, Kermott CA, Murad MH (2011) Gynecomastia - evaluation and current treatment options. TherClin Risk Manag 7: 145-148.

2. Ronald S. Swerdloff, MD, Jason Ng, MD, and Gladys E. Palomeno(2011)Gynecomastia: Etiology, Diagnosis, and Treatment Chapter 14.

3. Ansstas G, Griffing GT (2014) Gynecomastia.

4. Ankarberg-Lindgren C1, Norjavaara E (2008) Twenty-four hours secretion pattern of serum estradiol in healthy prepubertal and pubertal boys as determined by a validated ultra-sensitive extraction RIA. BMC EndocrDisord 8: 10 .

5. de Ronde W1, de Jong FH (2011) Aromatase inhibitors in men: effects and therapeutic options. ReprodBiolEndocrinol 9: 93.

6. Crowley WF, Pittleloud N (2013)Diagnosis and treatment of delayed puberty.

7. Jenny Bergquist (2005)Delayed Puberty.

8. Marshall WA, Tanner JM (1969) Variations in pattern of pubertal changes in girls. Arch Dis Child 44: 291-303.

9. Mahoney CP (1990) Adolescent gynecomastia. Differential diagnosis and management. PediatrClin North Am 37: 1389-1404.

10. Pralong F and Corwley (1999) Diagnosis and treatment of delayed puberty. American Family Physician 60: 1-7

11. Woelfle JF, Harz K, Roth C (2007) Modulation of circulating IGF-I and IGFBP-3 levels by hormonal regulators of energy homeostasis in obese children. ExpClinEndocrinol Diabetes 115: 17-23.

12. Bulard J, Mowszowicz I, Schaison G (1987) Increased aromatase activity in pubic skin fibroblasts from patients with isolated gynecomastia. J ClinEndocrinolMetab 64: 618-623.
13. Bidlingmaier F, Knorr D (1973) Plasma testosterone and estrogens in pubertal gynecomastia. Z Kinderheilkd 115: 89-94.

14. Biro FM, Lucky AW, Huster GA, Morrison JA (1990) Hormonal studies and physical maturation in adolescent gynecomastia. J Pediatr 116: 450-455.

15. Juul A, Holm K, Kastrup KW, Pedersen SA, Michaelsen KF, et al. (1997) Free insulin-like growth factor I serum levels in 1430 healthy children and adults, and its diagnostic value in patients suspected of growth hormone deficiency. J ClinEndocrinolMetab 82: 2497-2502.

16. Kleinberg DL, Feldman M, Ruan W (2000) IGF-I: an essential factor in terminal end bud formation and ductal morphogenesis. J Mammary Gland Biol Neoplasia 5: 7-17.

17. Limony Y, Friger M, Hochberg Z (2013) Pubertal gynecomastia coincides with peak height velocity. J Clin Res PediatrEndocrinol 5: 142-144.

18. Rosenfield RL, Bordini B, Yu C (2012) Comparison of detection of normal puberty in boys by a hormonal sleep test and a gonadotropinreleasing hormone agonist test. J ClinEndocrinolMetab 97: 4596-4604.

19. Tussete,Trarbach EB, Silveria LF et al. (2011) Clinical and molecular aspects of congenital isolated hypogonadotropichypogonadism. Arg Bras EndocrinolMetabol 55:501-11

20. Jungmann E, Trautermann C (1994) [The status of the gonadotropin releasing hormone test in differential diagnosis of delayed puberty in adolescents over 14 years of age]. Med Klin (Munich) 89: 529-533.

21. Prasad HK, Khadilkar VV, Jahagirdar R, Khadilkar AV, Lalwani SK (2012) Evaluation of GnRH analogue testing in diagnosis and management of children with pubertal disorders. Indian J EndocrinolMetab 16: 400-405. 